\title{
The Relationship Between Economic Growth and Inflation in the South African Economy
}

\author{
Wiza Munyeka \\ Department of Business Management, University of Limpopo (Turf loop Campus), \\ Private Bag X 1106. Sovenga, 0727. South Africa. \\ Email address: masterwiza2000@yahoo.com
}

\section{Doi:10.5901/mjss.2014.v5n15p119}

\begin{abstract}
The debate about the relationship between inflation and economic growth is important for the conduction of monetary policy. Given the relevance of this area of study, an important number of theories and models in the macroeconomic literature analyze the relationship between economic growth and inflation. The relationship of these macroeconomic variables is critical for the proper formulation and implementation of effective monetary policy (Akinboade, 2002). The current study adopted a quantitative study design to be able to determine the relationship between economic growth and inflation and also to explain variations between them. The study relies mainly on the quarterly secondary data. The sample size to be used is 18 years which is from 1993 to 2011 being quarterly data which was based on pre-inflation targeting 1993 to 1999 quarterly data and post-inflation targeting 2000 to 2011 quarterly. The data was obtained from various data sources and institutions, Stats South Africa and also on these websites www.easydata.co.za and www.tradingeconomics.com. The estimated model also used to analyze the study was the linear regression model; hence relevant literature was reviewed concerning the relationship. To analyze the data the study used the EViews 7 statistical programme. The findings indicated that white tests indicating non present of heteroscedasticity in the data. When there is heteroscedasticity it is the absence of homoscedasticity.
\end{abstract}

Keywords: Congress of South African Trade Unions (COSATU); heteroskedasticity; homoscedasticity; Inflation targeting; Monetary Policy Committee (MPC); Stats South Africa; South African Reserve Bank (SARB) ;

\section{Background}

The South African Reserve Bank through monetary policy provides an enabling environment for the economy to expand in line with its full production potential without giving in to inflationary pressures. The gains associated with the economy operating at full potential are employment, high incomes and rise in living standards. As a result, the Reserve Bank provides fundamentals to boost confidence on economic agents. A stable financial environment is characterized by an effective regulatory infrastructure, effective financial markets and, effective and sound financial institutions (Khan \& Senhadji, 2001).

The Monetary Policy Committee (MPC) has tightened monetary policy by further increasing the repo rate since June 2007. In order to address the issue of monetary policy relevance to the problem of inflation and low economic growth, there is need for an appropriate framework that serves as a reference point. It is important to understand the underlying interrelationships between monetary policy instruments and targets in order to understand the relevant policy variables needed to address the problems at hand. In addition, an understanding of how monetary policy impacts on the economic environment is very crucial for the choice of policy variables in dealing with both of inflation and economic growth in South Africa (SARB, 2010).

These characteristics signal the Reserve Bank's commitment to financial stability. Monetary policy can prevent changes in money supply to contribute to aggregate demand fluctuations. In the short run, the Reserve Bank reduces volatility in output and employment. Thus, monetary policy can smooth out fluctuations associated with business cycles to stabilize the economy. The Monetary Policy Committee takes action about the interest rates policy to bring inflation up, or down, when the inflation rate bounces outside the targeted rage, formerly 2008 between $3 \%$ and $6 \%$. South Africa sometimes experience inflation rates above its targeted range due to, among other factors, food and fuel costs (Mboweni, 2005).

According to Du Plessis (2005) Inflation is not neutral, and in no case does it favour rapid economic growth many central banks around the world, including the South African Reserve Bank (SARB) have adopted inflation targeting frameworks as their monetary policy stance in order to achieve low levels of inflation and attain price stability. 


\section{Statement of Problem}

The problem to be investigated by the current study is to analyze and determine the relationship between economic growth and inflation in the South African economy. There is a growing body of literature on the inflation-growth relationship debate regarding South African economy as well as other African countries since in the past.

Many studies have focused on developed countries only. The problem regarding the relationship between these two macroeconomic concepts has received much attention from economists and policy makers around the world and there were reaching various conclusions regarding the relationship, some arguing that there is positive relationship some argue there is a negative relationship. However the purpose of this study is to thoroughly investigate this important relationship. As far as macroeconomics and the conduct of monetary policy are concerned there are areas where there is disagreement, about how the South African reserve bank should conduct monetary policy framework. This gives attention to the enquiry that whether inflation targeting is relevant or contributing to low economic growth as being one of the research objectives.

\section{Research Aim and Objectives}

\subsection{Aim of the study}

- the aim of the study is to analyse the relationship between economic growth and inflation in the South African economy.

\subsection{Objectives of the Study}

The aim of the study is disaggregated into the following objectives:

- To determine whether economic growth can lead to inflation.

- To determine the impact of inflation on the economic growth.

- To determine whether inflation targeting contribute to lower economic growth.

\subsection{Significance of the Study}

Currently, economists and most theories seems to agree that high rates of inflation cause problems, not just for some individuals, but for aggregate economic performance (Gillman, Harris \& Matya 2004). However, much less agreement exists about the precise relationship between inflation and economic performance, and the mechanism by which inflation affects economic activity. Inflation and low economic growth are perhaps the two most important challenges that face the South African economy and policy formulators in the economy today. The problem of high inflation and low economic growth is very common in south Africa this leads to a need to develop studies that aims to find the relationship between inflation and economic grow in South Africa economy, and if is there any relationship between economic growth and inflation.

\subsubsection{Economic Growth}

According to Nell (2000) economic growth is the most important single measure of the performance of an economy. It generally involves an increase in the volume of goods and services that an economy produces over a period of time. It is measured by the annual rate of change in the gross domestic product. According to McConnell (2000) economic growth is the increase in value of the goods and services produced by an economy. It is conventionally measured as the percent rate of increase in real gross domestic product, or GDP. Growth is usually calculated in real terms such as inflationadjusted terms, in order to net out the effect of inflation on the price of the goods and services produced perhaps since it tells them what happens in the economy.

\subsubsection{Inflation}

According to Mishkin (2001) inflation is a rise in the general level of prices of goods and services in an economy over a period of time. When the general price level rises, each unit of currency buys fewer goods and services. Consequently, 
inflation also reflects erosion in the purchasing power of money a loss of real value in the internal medium of exchange and unit of account in the economy. A great measure of price level is the inflation rate, the annualized percentage change in a general price index normally the Consumer Price Index over time. Inflation's effects on an economy are various and can be simultaneously positive and negative (Nell, 2000).

\subsubsection{The Relationship Between Output Growth and Inflation}

The is growing empirical research investigating the relationship between economic growth and inflation, however, most of the research has focused on groups of industrial and developing countries and there has been very little research on individual countries, including South Africa. Economic theories reach a variety of conclusions about the responsiveness of output growth to inflation. Theories are useful, as they account for some observed phenomenon. The inflation-growth relationship has been debated for some time. Inflation can have three possible effects on growth: a positive effect, a negative effect and no effect at all. It is generally agreed that high levels of inflation would have a negative impact on growth, but certain inflation thresholds could have a positive effect on growth. It is also agreed that the relationship to be either negative or positive it also lays on the reliability of the model used to test that particular relationship between this two macroeconomic variables (Burdekin \& Weidenmier 2002).

According to economic theory, the negative effect on growth is thought to happen at a particular inflation rate known as the inflation threshold. Beyond this inflection point, there is a negative relationship between inflation and growth in both directions. Below it, no relationship and in some cases a positive relationship. Inflation uncertainty may also have an effect on economic growth. Theory shows that inflation uncertainty may have a greater negative effect on growth than the level of inflation (Hodge, 2006). Empirical evidence provides support to the theoretical studies. The empirical literature is divided into three sections; cross-country analysis, single country analysis and studies on South Africa. In terms of the relationship between inflation and growth, empirical literature shows that there is a negative relationship between inflation and growth for the majority of the studies. This applies to South Africa as well. In terms of the inflation threshold level, empirical literature shows that inflation threshold levels exist for all but a few of the countries. From 2000 onwards when inflation targeting was implemented, there were fewer fluctuations in both the inflation rate as well as the GDP growth rate. This is in support of the inflation targeting objectives: a lower inflation rate will lead to a more sustained growth rate with fewer fluctuations (Epstein, 2003).

A long-run relationship between inflation and economic growth does not imply causality. In terms of the volatility of inflation, there is a strong positive relationship between the inflation rate and the volatility of inflation. However, it is unclear as to whether it dampens economic growth since the implementation of inflation targeting it is apparent that over the years employment has largely remained positive. It also shows that employment has also been less volatile since the implementation of inflation targeting. This suggests that low inflation levels promote job creation by increasing economic growth in the economy (Khan, 2001).

\section{How Economic Growth Can Lead to Inflation}

Sustained growth caused by rising aggregate demand can lead to acceleration in inflation as the economy uses up scarce resources and short run aggregate supply becomes inelastic. When SRAS is elastic, an outward shift of aggregate demand can easily be met by a rise in real GDP which means there is plenty of spare capacity and supply responds elastically to the higher level of $A D$, but when SRAS becomes inelastic, the trade-off between growth and inflation worsens. An increase in $A D$ tends to lead to higher prices rather than increased output and employment. The tradeoff between growth and inflation can be avoided if an economy is able to increase potential output by improving their supplyside performance. For example, LRAS can be increased by achieving sustained improvements in productivity, advances in technology and the benefits that come from product and process innovations. Potential output is also increased by expanding the stock of capital goods through higher investments and through an increase in the available labour supply. An outward shift in LRAS means that the economy can meet a higher level of aggregate demand without putting upward pressure on the general price level (Gillman, Harris \& Matya, 2004).

According to Bain \& Howells (2009) structuralists argue that inflation is needed for economic growth, whereas monetarists argue that inflation is harmful to economic growth. The structuralists' view of inflation is that up until a certain critical inflation rate, there is a positive relation between inflation and growth. Because of factor immobility and downward rigidity of factor prices, structural imbalances that arise from expanding and declining sectors of the economy are inflationary. Upward movements in wages and prices are, however, necessary to reallocate scarce resources in the most efficient way. The inevitable trade-off between growth and inflation suggests that higher growth and lower unemployment 
can only be achieved at the cost of some inflation, this suggest that the structuralists description of the relationship between inflation and growth is bi-directional.

\section{The Impact of Inflation on Economic Growth}

Inflation has been shown to reduce economic activity and therefore growth in many ways. Individuals and businesses try to protect their wealth from inflation and in doing so waste time and resources. Therefore, inflation brings about inefficiencies that lead to the misallocation of resources and a general decline in macroeconomic performance .Reduced savings lead to reduced investments, which in turn reduce economic growth level. General uncertainty about future price levels discourages investment, leading to a lower capital stock in the economy. Furthermore, the returns on investments are reduced by inflation; therefore investors will invest in short-term capital rather than making long-term investments. Investors would also rather invest in assets that can hedge against inflation (property, equity) rather than productive assets such plant and equipment (Jones \& Manuelli, 2001).

This may lead to an asset price bubble in inflation hedge assets. It also reduces the economy's production capacity therefore reducing economic growth, labour negotiations waste resources and push up nominal wages leading to unproductiveness and therefore lower growth. Inflation variability leads to shorter average contract lengths. Therefore resources are wasted in continual renegotiating of these contracts. Reduced competition, domestically and internationally reduces investment and therefore growth. Higher inflation reduces competitiveness in the goods sector with trading partners, reducing trade and therefore causing an imbalance in the balance of payments account in the way of a current account deficit (Ambler, 2003). Less investment will flow into the country in the goods sector and so prevent the country's ability to reduce its current account deficit. In addition, with the reduced competition in international markets, profits in the traded goods sector will decline. In essence, resources will move away from the traded goods sector and into the nontraded goods sector.

Inflation understates the real value of depreciation. Therefore higher profits are declared resulting in higher tax paid on profits. This disadvantages companies wanting to make additional investments. According to Modigliani (2000), inflation imposes costs on the economy which lead to wasted time and resources and therefore a decline in economic growth. Stockman (2005) discusses an economy in which individuals divide their wealth between two assets, namely money and capital stock, and real money is spent on consumption and investment. At higher inflation levels, consumption decreases and investment increases as investment will have a higher return. However, with the low return on money, the net return is low. Therefore investment and capital stock are lowered. So economic growth declines due to lower consumption, lower investment and lower capital stock.

When there is higher inflation there are several possibilities, the first is an increase in the growth rate because, as depreciation rises, the tax paid on capital is reduced. The second effect is a decrease in the growth rate. As the money supply increases, so do the nominal interest rates. Tax credits on depreciation are reduced, resulting in an increase in the cost of capital. The third is dependent on the impact of inflation on the labour-leisure choice. Assuming cash goods and credit goods are substitutes for each other, increasing the price of cash goods will see consumption move away from cash goods and towards credit goods, causing the growth rate to first decrease then increase (Hodge, 2006).

If cash goods and credit goods are complements, price increases in cash goods will result in consumption of cash and credit goods both decreasing and therefore increase the demand for leisure goods. This will cause a drop in the growth rate (Jones \& Manuelli. 2001). The inflation rate is positively related to the level of uncertainty in the economy. Higher inflation is associated with more variations in inflation, which ultimately lead to uncertainty (Jackman, Mulvey \& Trevithick, 2004). Uncertainty about the inflation rate creates confusion regarding buying, selling, borrowing and investing. For any of these, one needs to base decisions on current and future prices. Uncertainty creates confusion about these prices, therefore discouraging investment and leading to a lower capital stock in a country, is a higher chance of correctly forecasting shorter-term prices than longer-term ones (Briault, 2007). However, willing investors will expect to be compensated for their risk due to the increased uncertainty making investing more costly for borrowers. A higher risk premium leads to higher real rates, which further discourage investment and result in lower capital stock to protect their income from inflation, individuals will divert time and resources away from their usual productive activities into redistributing their income.

\section{Inflation Targeting and Economic Growth}

In February 2000 it was announced that formal inflation targeting will be adopted in South Africa as the monetary policy framework by the South African Reserve bank. South African reserve bank was to specify the target in terms of an annual 
average rate of increase in the CPIX for the calendar year 2002. A multi-year target approach was followed by specifying the target as an average annual rate of increase of between 3 and 6 per cent in the CPIX for the years 2002 and 2003, and an increase of between 3 and 5 per cent for the years 2004 and 2005. When it became clear that the inflation target would be missed for a fairly protracted period due to a sharp depreciation in the external value of the rand and a number of other exogenous shocks, the target range for 2005 was increased from 3 to 5 per cent to 3 to 6 per cent (Mboweni, 2005). Some commentators and economists on monetary policy, particularly labour organisations, argue that inflation targeting leads to an overemphasis on monetary stability at the cost of growth and development, and reduces flexibility in dealing with exogenous shocks to the economy. Although they agree that low inflation and high economic growth are both desirable objectives, they are of the opinion that in the current situation of high unemployment and low economic growth in South Africa, the cost of reducing inflation is unacceptably high. The trade-off between inflation and unemployment has received considerable attention since 1958, when Philips argued that monetary policy could maintain a permanently lower rate of unemployment by accepting some degree of inflation, and also the other way (Epstein, 2008).

According to Aron (2001) the use of monetary policy by the monetary authorities to reduce or moderate inflation led to criticism made against inflation targeting by organisation such as COSATU their argument is that, inflation targeting has contributed directly to slowing down the rate of economic growth and this of job creation and poverty alleviation. COSATU's argument is that the SARB should run an expansionary monetary policy, allowing inflation to increase in order for unemployment to decline. Theoretically, this tradeoff between inflation and unemployment or growth implies a reiteration of the widely discredited Phillips curve effect.

Akinboade (2003) also suggest that the structural nature of South African inflation is likely to make any inflation targeting regime slow and costly in terms of output and employment. However, COSATU's argument is inconsistent on two levels while there does seem to be a relationship between short term inflation and output in South Africa, no such relationship exists between inflation and unemployment.

\section{Methodology}

\subsection{Research design}

The research study adopted the quantitative study design to be able to determine the relationship between economic growth and inflation also to explain variations between them.

\subsection{Area of the Study}

The area of study is the South African economy and the study sought out to understand this important correlation between economic growth and inflation. The study chose to use the sample period, 1993 to 2011 for which data is collected, analysed and interpreted. Once the relationship is clarified between these variable this can assist in policy formulation since the trends of the variables will be known.

\subsection{Data Collection}

The current study relies mainly on the quarterly secondary data. The sample size to be used is 18 years which is from 1993 to 2011 being quarterly data which will be based on pre inflation targeting 1993 to 1999 quarterly data and post inflation targeting 2000 to 2011 quarterly. The data is obtained from various data sources and institutions, Stats SA and also on these websites www.easydata.co.za and www.tradingeconomics.com.

\subsection{Data Analysis}

The purpose for obtaining such data is to compare fluctuations of economic growth and inflation rate during pre and post inflation targeting and their relationship, but much attention concerning models it will be given to post inflation targeting data while pre inflation targeting data is represented by econometric graphs. The data represent two variables independent and dependent which are economic growth and inflation respectively. In this section, the study examine the economic growth-inflation relationship using econometric techniques such as correlation analysis, econometric graphs and the diagnostic tests will be carried out to ensure that the data is reliable and is not affected by issues such as serial correlation or heteresdostecity. The estimated model also used to analyze the study is the linear regression model, hence relevant literature is reviewed concerning the relationship. To analyze the data the study is using the EViews 7 statistical 
programme.

The model equation $Y=\beta 0+\beta 1 X 1+U$

$Y$ - Dependent variable which is the inflation rate expressed as a percentage

$\beta 0$ - intercept of the regression model

$\beta 1$-slope of the regression model

$\mathrm{X} 1$-independent variable which is economic growth rate

$\mathrm{U}$ - Error term reflect that this is an estimated model not actual relationship of the variables.

\subsection{Ethical Consideration}

The study was done by using reliable secondary quarterly data which was not manipulated.

\section{Data Presentation, Research Results and Analysis}

The quarterly data in table 1 and table 2 was used in the conducted research Post inflation targeting 2000-2011 quarterly data

\begin{tabular}{|c|c|c|}
\hline Quarterly & Economic growth rate \% & Inflation rate $\%$ \\
\hline 2011 December & 3.2 & 6.1 \\
\hline 2011 September & 1.4 & 5.7 \\
\hline 2011 June & 1.3 & 5 \\
\hline 2011 March & 4.6 & 4.1 \\
\hline 2010 December & 4.5 & 3.5 \\
\hline 2010 September & 3.1 & 3.2 \\
\hline 2010 June & 2.8 & 4.2 \\
\hline 2010 March & 4 & 5.1 \\
\hline 2009 December & 3.5 & 6.3 \\
\hline 2009 September & 1.8 & 6.1 \\
\hline 2009 June & -2.8 & 6.9 \\
\hline 2009 March & -6.3 & 8.5 \\
\hline 2008 December & -1.7 & 9.5 \\
\hline 2008 September & 1.8 & 13.1 \\
\hline 2008 June & 4.5 & 12.2 \\
\hline 2008 March & 2.9 & 10.6 \\
\hline 2007 December & 6 & 9 \\
\hline 2007 September & 5 & 7.2 \\
\hline 2007 June & 3.1 & 7.1 \\
\hline 2007 March & 6.5 & 6.1 \\
\hline 2006 December & 6.3 & 5.8 \\
\hline 2006 September & 4.6 & 5.3 \\
\hline 2006 June & 6.2 & 4.9 \\
\hline 2006 March & 5.9 & 3.4 \\
\hline 2005 December & 4 & 3.6 \\
\hline 2005 September & 5 & 4.3 \\
\hline 2005 June & 5.6 & 2.8 \\
\hline 2005 March & 4.3 & 3 \\
\hline 2004 December & 3.6 & 3.3 \\
\hline 2004 September & 7.2 & 1.3 \\
\hline 2004 June & 6.6 & 1.2 \\
\hline 2004 March & 6.1 & 6.4 \\
\hline 2003 December & 2.8 & 0.4 \\
\hline 2003 September & 2.4 & 3.8 \\
\hline 2003 June & 2.2 & 6.7 \\
\hline 2003 March & 2.8 & 10.2 \\
\hline 2002 December & 3.4 & 12.4 \\
\hline 2002 September & 4.6 & 11.1 \\
\hline 2002 June & 5.2 & 8 \\
\hline 2002 March & 4.3 & 6.3 \\
\hline
\end{tabular}




\begin{tabular}{lcc}
\hline 2001 December & 3.1 & 4.5 \\
2001 September & 1.1 & 4.4 \\
2001 June & 2 & 6.4 \\
2001March & 2.6 & 7.4 \\
2000 December & 3.4 & 7 \\
2000 September & 4 & 7.1 \\
2000 June & 3.7 & 5.1 \\
2000 March & 4.6 & 2.4 \\
\hline
\end{tabular}

Table 1: 2000-2011 quarterly data Pre inflation targeting 1993-1999 quarterly data

\begin{tabular}{|c|c|c|}
\hline Quarterly & Economic growth rate $\%$ & Inflation rate $\%$ \\
\hline $\begin{array}{l}1999 \text { December } \\
1999 \text { September } \\
1999 \text { June } \\
1999 \text { March }\end{array}$ & $\begin{array}{l}4.5 \\
4.4 \\
3.2 \\
3.7\end{array}$ & $\begin{array}{l}2.2 \\
1.9 \\
7.2 \\
7.9\end{array}$ \\
\hline $\begin{array}{l}1998 \text { December } \\
1998 \text { September } \\
1998 \text { June } \\
1998 \text { March }\end{array}$ & $\begin{array}{l}0.4 \\
-0.9 \\
0.6 \\
1.1\end{array}$ & $\begin{array}{c}8.9 \\
9 \\
5.3 \\
5.4\end{array}$ \\
\hline $\begin{array}{l}1997 \text { December } \\
1997 \text { September } \\
1997 \text { June } \\
1997 \text { March }\end{array}$ & $\begin{array}{l}0.1 \\
0.4 \\
2.5 \\
2.1\end{array}$ & $\begin{array}{l}6.3 \\
8.1 \\
8.7 \\
9.7\end{array}$ \\
\hline $\begin{array}{l}1996 \text { December } \\
1996 \text { September } \\
1996 \text { June } \\
1996 \text { March }\end{array}$ & $\begin{array}{l}3.8 \\
4.9 \\
4.9 \\
7.6\end{array}$ & $\begin{array}{l}9.3 \\
8.3 \\
6.8 \\
6.1\end{array}$ \\
\hline $\begin{array}{l}1995 \text { December } \\
1995 \text { September } \\
1995 \text { June } \\
1995 \text { March }\end{array}$ & $\begin{array}{l}1.4 \\
2.7 \\
1.2 \\
1.1\end{array}$ & $\begin{array}{c}6.9 \\
6.9 \\
10.2 \\
10.4\end{array}$ \\
\hline $\begin{array}{l}1994 \text { December } \\
1994 \text { September } \\
1994 \text { June } \\
1994 \text { March }\end{array}$ & $\begin{array}{c}7.6 \\
4.6 \\
4 \\
-0.1\end{array}$ & $\begin{array}{c}9.9 \\
10.3 \\
7.3 \\
9.2\end{array}$ \\
\hline $\begin{array}{l}1993 \text { December } \\
1993 \text { September } \\
1993 \text { June } \\
1993 \text { March }\end{array}$ & $\begin{array}{l}3.5 \\
5.2 \\
5.2 \\
4.1\end{array}$ & $\begin{array}{c}9.4 \\
8.7 \\
10.1 \\
9.5\end{array}$ \\
\hline
\end{tabular}

Table 2: 1993-1999 quarterly data

The regression model is based on post inflation 2000-2011 quarterly data. 


\subsection{Regression Model Results}

Dependent Variable: INFLATION_RATE

Method: Least Squares

Date: 09/26/12 Time: 22:30

Sample: 2000Q1 2011Q4 Included observations: 48

\begin{tabular}{lcccc}
\hline \multicolumn{1}{c}{ Variable } & Coefficient & Std. Error & t-Statistic & Prob. \\
\hline \multicolumn{1}{c}{ Economic_Growth_Rate } & 7.227711 & 0.736865 & 9.808731 & 0.0000 \\
\multicolumn{1}{c}{ C } & -0.389269 & 0.174240 & -2.234096 & 0.0304 \\
Adjusted R-squared & 0.097883 & Mean dependent var & & 5.875000 \\
S.E. of regression & 0.078272 & S.D. dependent var & & 3.030519 \\
Sum squared resid & 2.909500 & Akaike info criterion & 5.014613 \\
Log likelihood & 389.3987 & Schwarz criterion & 5.092580 \\
F-statistic & -118.3507 & Hannan-Quinn criter. & 5.044077 \\
Prob(F-statistic) & 4.991183 & Durbin-Watson stat & & 0.350765 \\
\hline
\end{tabular}

Figure 1: Regression model results

$$
\begin{gathered}
Y=7,227711-0,389269 x \\
\beta 0=7,227711 \\
\beta 1=-0,389269 x
\end{gathered}
$$

The $\beta 1$ coefficient is negative indicating a negative relationship between the variables. $R$ squared $=0,097883$ which means $9,7883 \%$ variation in inflation rate is accounted for by changes in economic growth rate this reflect that changes in economic growth rate has a small impact on either increase or decrease in inflation rate, which means inflation rise or decline as a result of other factors such as increase in money supply as a result of expansionary monetary policy also increase credit demand or inflation may decline as a result of decrease in the money supply when the authorities increase the repo rate.

Change in $y /$ change in $x-0,389269 / 1 \times 10 / 10=-3,89269$ this means that if there is $10 \%$ increase in economic growth this will lead to $-3,89269$ decline in inflation rate this also indicate that there is a negative relationship between economic growth and inflation hence these variables will move in opposite direction. Therefore, overall these results show that there is a significant negative impact of inflation on economic growth

Testing for the significance of the coefficients

$\mathrm{Ho}: \beta \mathrm{O}=0$

$\mathrm{Ho}: \beta 0>0$

At $5 \%$ level of significant $>0,0000 \mathrm{PV}$ which is the probability value

At $5 \%$ level of significant there is enough evidence in the data to reject Ho that

$\beta 0>0$, meaning $\beta 0$ is statistically significant.

$\mathrm{Ho}: \beta 1=0$

Ho: $\beta 1<0$

At $5 \%$ level of significant there is enough evidence in the data to reject Ho that is $\beta 1<0$, meaning $\beta 1$ is stastically significant.

The $\operatorname{prob}(\mathrm{F}$-statistic) which is the probability value for the F-statistic and it is greater than the level of significance $5 \%$ meaning $\mathrm{HO}$ is rejected; $\mathrm{R}$ squared $>0$ LOS $0,05>$

PV 0,030379 this reflects that the model being used is of good fit and it's reliable.

\subsection{Correlation Analysis Results}

Date: 09/26/12 Time: 22:53

Sample: 2000Q1 2011Q4

Included observations: 48

\begin{tabular}{lcc}
\hline \multicolumn{1}{c}{ Correlation } & Inflation_Rate & Economic_Growth_Rate \\
\hline Inflation_rate & 1.000000 & -0.312863 \\
Economic_growth_rate & -0.312863 & 1.000000 \\
\hline
\end{tabular}

Figure 2: Correlation analysis results 
Correlation and regression analysis are related in the sense that both deal with relationships among variables. Values of the correlation coefficient are always between -1 and +1 . A correlation coefficient of +1 indicates that two variables are perfectly related in a positive linear sense, a correlation coefficient of -1 indicates that two variables are perfectly related in a negative linear sense, and a correlation coefficient of 0 indicates that there is no linear relationship between the two variables.. Apart from the least squares regression results, the results for correlation analysis clearly indicate a negative correlation of $-0,312863$ between economic growth and inflation rate .

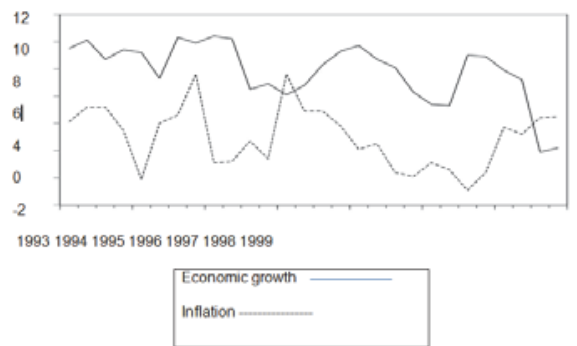

Figure 3: Pre inflation targeting 1993-1999 quarterly data

The figure above suggests that the seven years period before inflation targeting showed lower economic growth and higher inflation which sometimes was above $10 \%$, hence there was no inflation targeting and also this high inflation was experienced at a lower economic growth since high inflation is detrimental for economic growth and stability. The graph for pre inflation targeting shows that the relationship between economic growth is negative between 1995 and 1996 and also from 1996 to 1997 inflation was rising while economic growth was declining hence also this indicate a negative relationship between them. Inflation and economic growth were much volatile before the adoption of the 3\%-6\% bend inflation targeting and economic growth was much volatile during the period of 1998 while inflation was high. The major conclusion from the above graph can be that inflation was very high before the adoption of inflation targeting while economic growth was low being also negative during the period of 1998.

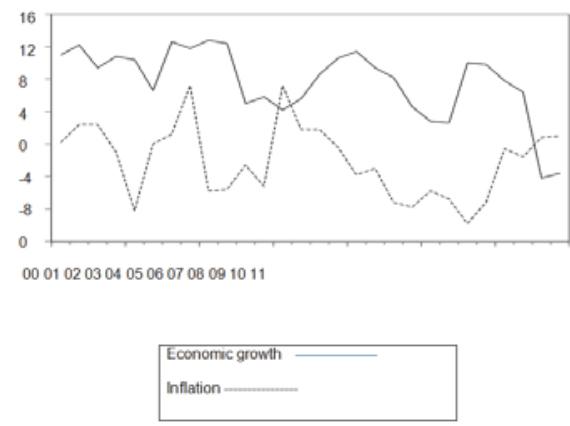

Figure 4: Post inflation targeting 2000-2011 quarterly data

Since February 2000 South Africa has been relying on an inflation-targeting framework focused primary on achieving low and stable inflation which is carried out by the central bank the South African reserve bank (Handa, 2005). The graph above shows that after the adoption of inflation targeting inflation came down during the years 2003, 2004 and 2005 it was within the bend of $3 \%-6 \%$ while economic growth was increasing positively. This indicate that low inflation create an environment for stable economic growth. The graph also indicate a negative relationship in 2000 inflation was rising while economic growth was declining also during the period of 2003 economic growth was rising while inflation was declining. Also during 2006 the graph shows this negative relationship between these two macroeconomic variables. During the period of 2008 to 2009 economic growth was very low since it represent the period of economic recession that occurred during that period. Inflation was also high during that particular period of recession. The end of 2009 the economy was starting to recover economic growth was rising while inflation was coming down and also in 2010 and 2011 the economy was growing while inflation was declining this also indicate this negative relationship between these two variables. The major conclusion from the graph above is that inflation targeting reduced inflation and economic growth volatility. 
Economic growth is much impressive than before inflation targeting was introduced and inflation is much low this shows that the adoption of inflation targeting by the monetary authorities it was a good decision since this had a positive effect on macroeconomic stability and growth.

\subsection{Diagnostic Tests}

Diagnostic tests are carried out to ensure that the data being analysed is reliable and ensure that deceptive results are obtained.

\begin{tabular}{|c|c|c|c|c|}
\hline Test & Ho & $\begin{array}{c}\text { Test } \\
\text { Statistic }\end{array}$ & P-Value & Conclusion \\
\hline Jarque Bera & $\begin{array}{l}\text { Disturbance terms are normally } \\
\text { distributed }\end{array}$ & 4.172228 & 0.124169 & Do not reject Ho \\
\hline $\begin{array}{l}\text { Breusch- } \\
\text { Godfrey }\end{array}$ & No serial correlation & 0.404006 & 0.5250 & $\begin{array}{c}\text { Do not reject Ho PV > LOS: There is no serial } \\
\text { correlation }\end{array}$ \\
\hline ARCH LM & Heteroskedasticity is present & 21.31239 & 0.0000 & Reject Ho PV < LOS: Heteroskedasticity is present \\
\hline White without ct & No heteroskedasticity & 0.029912 & 0.8627 & $\begin{array}{c}\text { Do not reject Ho PV > LOS: There is no } \\
\text { heteroskedasticity }\end{array}$ \\
\hline White with ct & No heteroskedasticity & 0.764546 & 0.6823 & $\begin{array}{c}\text { Do not reject Ho PV > LOS: There is no } \\
\text { Heteroskedasticity }\end{array}$ \\
\hline
\end{tabular}

\subsection{Stability test}

Table 3: Diagnostic tests

\begin{tabular}{ccccc}
\hline Test & Ho & Test Statistic P-Value & Conclusion \\
\hline Ramsey test The equation is correctly specified & 0.844098 & 0.3582 Do not reject Ho PV > LOS: The model is of good fit \\
\hline
\end{tabular}

The possible existence of heteroscedasticity is a major concern in the application of regression analysis, including the analysis of variance, because the presence of heteroscedasticity can invalidate statistical tests of significance that assume that the modelling errors are uncorrelated and normally distributed and that their variances do not vary with the effects being modelled. Similarly, in testing for differences between sub-populations using allocation, some standard tests assume that variances within groups are equal. In our case white tests indicate non present of heteroscedasticity in the data. When there is heteroscedasticity it is the absence of homoscedasticity. The Ramsey RESET test was carried out and the key principle of carrying out this test is to determine if the model equation is correctly specified. If the equation of the model is incorrectly specified, it may lead to misspecification bias and wrong functional forms that would result into a high R squared and therefore, yielding misleading results.

\section{Conclusion and Recommendations}

\subsection{Conclusion}

The literature review provided some useful information into the relationship between inflation and economic growth. Most theories are in support of a negative relationship with the belief that inflation imposes costs on an economy thereby reducing growth. The results being analysed also suggest the existence of a negative relationship between these two macroeconomic variables in the South Africa economy. The argument that inflation targeting has limited employment creation and also economic growth, is weak at best and not reliable and valid, simply ignores the true determinants of unemployment in South Africa (Gruen, Romalis \& Chandra, 1999). While by no means a perfect system, the transparency and clear targets of inflation targeting means that it remains the best possible policy with which to stabilize inflation and the macroeconomic environment and, thereby, promote growth in South African economy. The argument by organisation such as COSATU that inflation targeting limit job creation it may be viewed as untrue while there does seem to be a relationship between inflation and growth in South Africa, no such relationship exists between inflation and unemployment (Muellbauer \& Banco, 2001).Instead South Africa's unemployment rate is unresponsive to both inflation and growth due to the structural inflexibility of its labour market. Lastly economic growth can lead to inflation if it rises because of excessive aggregate demand which exceed the aggregate supply in the economy. 


\subsection{Recommendations}

In the presence of a sustained inflation in South Africa which can be regarded as a monetary phenomenon. In this case, the main aim of monetary policy should be the pursuit of a low and stable rate of inflation. Once this is achieved, a conducive economic environment is created and finally economic expansion leads to reduced unemployment rate in South Africa (Huchet, 2003). The monetary authorities should not abandon inflation targeting framework hence it helps avoid time inconsistency in monetary policy and helps keep the public informed. It helps to ease the effect of external shocks on the economy and avoid radical shifts in monetary policy. It helps anchor the expected inflation and also to avoid political interference in monetary policy. South African government should try to have employment targets they should consider to pursue supply-side policies to improve the structure and functioning of the labour market rather than demand management policies (Karanassou, Sala \& Snower, 2007). The policies that can reduce unemployment in South Africa are, to increase the incentive to work through reductions in marginal tax rates, improve flexibility of wages and working practice, and improve the market efficiency of the goods through privatization. Unemployment and low economic growth should not be blamed on inflation targeting but rather much effective employment creation policies must be created by the government and also a great environment for much needed investments must be created.

\section{References}

Akinboade, O. A., Niedermeier, E.W. and Siebrits, F. K. (2002). The Dynamics of Inflation Targeting in South Africa: Implications for Policy. South African Journal

Ambler, T. (2003), Marketing and the Bottom Line - the Marketing Metrics to Pump up Cash Flow, 2nd edition. Financial Times I Prentice Hall.

Aron, J. and Muellbauer J., (2001), "New Monetary Policy Challenges for Sustainable Growth in South Africa." Research report ESCOR No.729, The U.K.

Department for International Development of Economics, 70(3): 462-485

Bain, K and Howells, P. (2009). Monetary Economics; Policy and its Theoretical Basis Palgrave Macmillan.

Briault, C. (2007). The costs of inflation. Bank of England. Quarterly Bulletin. 35, Feb: 33-45

Burdekin, R.C.K and Weidenmier, M.D. (2002), "Suppressing Asset Price Inflation: The Confederate Experience, 1861-1865," NBER Working Paper No. 9230 (forthcoming in Economic Inquiry).

Du Plessis, S. A. (2005). Proposals for Strengthening the SARB's Inflation Targeting Regime. South African Journal of Economics, 73(1): 337-354.

Epstein, G. (2003). Alternatives to inflation targeting monetary policy for stable and egalitarian growth - a brief research summary. Political Economy Research

Gillman M, Harris, M, N. and Matya, L. (2004). Inflation and growth: explaining a negative effect. Empirical Economics. 29: 149-167.

Gruen, D., Romalis, J. and Chandra, N.(1999), "The lags of monetary policy", Research Discussion Paper 9702, Reserve Bank of Australia

Handa, J., (2005), Monetary economics, Routledge, USA.

Huchet M.B., (2003), "Inflation and the real effects of monetary policy", International Conference on Policy Modeling, Istanbul

Hodge, D 2006. Inflation and growth in South Africa. Cambridge Journal of Economics. (2006), 30: 163-180Kelly, P., 2008. Changes to the inflation target and headline inflation measures. Statistics South Africa. Pretoria: Stats SA

Jackman, R., Mulvey, C. and Trevithick, J., 2004. The Economics of Inflation. (2nd edn).Oxford: Martin Robinson.

Jones, L. E. and Manuelli. R. E., 2001. Growth and the effects of inflation. National Bureau of Economic Research. NBER Working Paper № 4523.

Karanassou, M, Sala, H. and Snower, D. J, (2007), "The Evolution of Inflation and Unemployment: Explaining the Roaring Nineties", Working Paper No.1350, Germany, [Online] Available: http://www.ifwkiel.de/pub/kap/kapcoll/kapcoll_02.htm

Khan, M. S. and Senhadji, A. S., 2001. Threshold effects in the relationship between inflation and growth. International Monetary Fund. Staff Papers. 48, 1: 1-21.

Mboweni T. (2005): The State of the South African Economy. Address at the Annual Dinner in Hour of the Ambassadors and High Commissioners to the Republic of

South Africa, Pretoria.

Mishkin, F. S., 2001. The economics of money, banking and financial markets. United States of America: Addison Wesley Longman

Muellbauer, A.J., and Banco, J., 2001. Estimating monetary policy rules for South Africa. Working Paper 89. Santiago: Central Bank of Chile

Nell, K. S., 2000. Is inflation and precondition for faster growth? The case of South Africa.

SARB, 2010. Understanding the core responsibilities of the bank: to maintain price stability and financial market stability. Pretoria: SARB. www. easydata.co.za (Accessed 2nd May, 2014)

www.tradingeconomics.com (Accessed $2^{\text {nd }}$ May, 2014) 